Instituto de Estudios Sociales Avanzados (CSIC) Working Paper 93-13

\title{
The vicissitudes of Spanish science and technology policy: coordination and leadership
}

Luis Sanz-Menéndez, Emilio Muñoz and Clara Eugenia García Consejo Superior de Investigaciones Científicas (CSIC) 


\title{
The vicissitudes of Spanish science and technology policy: coordination and leadership
}

\author{
Luis Sanz-Menéndez, Emilio Muñoz and Clara E García
}

$S \& T$ were low priorities in Spain until the mid70 s. The socialist government, aided by $S \& T$ policies elsewhere and the emerging policy entrepreneurs, made reforms to better co-ordinate public S\&T. Institutional weaknesses were an obstacle, initially masked by strong leadership, policy entrepreneurs, reduced bureaucratic powers, and poor representation of some groups.

Now, most mechanisms of public S\&T coordination have gone, with changes in the Interministerial Commission (CICYT) and elsewhere. Power has returned to the departmental bureaucracies, and again science has low status.

Restricted access to policy making, weak leadership, financial constraints, and emphasis on the private sector, are all reducing the stability of Spain's $S \& T$ system.

Luis Sanz-Menéndez and Emilio Muñoz are members of the Research Unit on Science and Technology Policy (RUSTEP), IESA (Institute for Advanced Social Studies of the CSIC), Alfonso XII 18, 28014 Madrid, Spain. Clara E García is a Research Associate of BRIE (Berkeley Roundtable on the International Economy), University of (Berkeley Roundtable on the International Economy), University

California, 2234 Piedmont Avenue, Berkeley, CA 94720 , USA.
This work was financially supported by NATO, the Spanish Minister of Education and Science, and the Madrid Office for Research Support of the Regional Government. The authors also express thanks for the institutional support of the Berkeley Roundtable on the Intemational Economy, Institute of International Studies, and Institute of Urban and Regional Development, all from the University of California at Berkeley.

The authors are grateful for the critical comments and suggestions from Luis Moreno, Ludolfo Paramio, Alfredo Cadenas, Paloma Sán chez, Carmela Martín, José Molero, José Antonio Martín Pereda Miguel Angel Quintanilla, Benjamin Coriat, and Giovanni Dosi. The authors are responsible for any remaining errors and deficiencies.
$\mathbf{I}$ N THE PAST TEN YEARS, Spain has faced a modernisation process following a complex democratic transition, and a major change ${ }^{1}$ involving a more European approach to structures and behaviour. To modernise meant to measure itself by European standards and to enter European institutions. Since 1982 a socialist government has ruled Spain and, in 1985, Spain joined the European Community. Science and new technology were at the forefront of the political concerns of the early socialist governments, ${ }^{2}$ in contrast to the previous Franco regime or to the government of the Unión del Centro Democrático. ${ }^{3}$

This article is about science and technology in the broad process of modernisation and change supported by the Spanish socialist government. That government brought about a quantitative and qualitative change in Spain S\&T, although the momentum has declined recently. ${ }^{4}$

This study analyses the public policy-making process for S\&T in Spain. It accepts that there is a place for such policy. as reflected in both neoclassic $^{6}$ and evolutionist ${ }^{7}$ economics. emphasises the public initiatives which come from S\&T policies, their definition, their implementation, the position and the role of responsible bodies in government, their efficacy and efficiency.

Our approach is mostly comparative, using the experience of other western countries, the USA in particular, and the aim is to understand the features that determine the outcomes of such policies.

This is not an analysis of the present situation, or the role of science and technology in the economy. ${ }^{5}$

For many years, public S\&T policies in general 
have meant ${ }^{8}$ the deliberate efforts of the political authorities to influence the direction and speed of the development of scientific and technical knowledge. They have used a series of promotional initiatives, financial resources, and administrative mechanisms. Some of these started as policies for science which progressed into policies for technology and, later, for innovation. ${ }^{7}$ This evolution explains why our definitions of science and of technology policies are generic, and often interchangeable.

In the mid-1980s a 'reform' of the S\&T system was initiated in Spain through the framework of a new law and a national R\&D plan. ${ }^{10}$ ) The aim was to guarantee a working $R \& D$ structure and greater rationality in public action. Spain was attempting, two decades later than its neighbours, to push forward with new S\&T policies. These were strongly supported, and given financial and other resources.

When we talk of the Spanish approach to Europe, we have in mind something like a rough standardisation or harmonisation of the region's S\&T policies, as well as of implementation and management procedures, and of the institutions responsible for them, along with their position and role in government. Elsewhere ${ }^{11}$ we have suggested that Spanish S\&T policies illustrate the international diffusion of public policies-or, at least, the diffusion of the 'rationale' for S\&T policies, the instruments being adapted to national needs.

In spite of the excitement generated by the reforms of the mid-80s amongst the Spanish political classes, our provisional assessment is not too favourable. Those initiatives have been abandoned, S\&T policy has lost its momentum, and the approach towards Europe has slowed greatly.

Thus our general thesis is that there is an imbalance, a permanent lagging behind of public initiative by the Spanish government, in matters scientific and technological, in comparison to more developed countries. Within this general diagnosis, ${ }^{12}$ a specific problem is the co-ordination of the different types of state initiative. ${ }^{13}$

The standing of science in the Spanish government is again reminiscent of that in many underdeveloped countries. ${ }^{14}$ This involves, firstly, a notable lack of co-ordination of public initiatives in S\&T independent of government Treasury funding and, secondly, the poor political and administrative standards of the body responsible for S\&T policies. ${ }^{15}$

\section{Problems of co-ordination}

Observers of S\&T policy have noted several stages in its development, and few resist the temptation to develop their own interpretations. It is commonly recognised ${ }^{16}$ that, although relations between science and power have been around since
The military and organisational success of the mobilisation of efforts, planning and co-ordinated action of the Manhattan project pointed to the potential of the science-state alliance, at least from the perspective of the aims of the major powers

time immemorial, they have been transformed since the Second World War.

Until the end of the 1930s, public support for research was not seen as utilitarian; scientists and institutions were allowed to determine their own priorities and programmes. Scientists were generally regarded as men in search of truth, seeking the advancement of knowledge; and it was felt that, for this reason, science should be supported. It was not yet overly expensive.

The 1940s atomic bomb Manhattan Project was a significant event which underlined a change in the way scientific priorities were understood. ${ }^{17}$ The military and organisational success of this mobilisation of effort, planning, and co-ordination, pointed to the potential of the science-state alliance, at least from the perspective of the aims of the major powers.

\section{Science in the US government}

In mid-1944 President Roosevelt had asked V Bush to prepare a report on science-state collaboration, and apply it to peacetime. The report, Science, the Endless Frontier, ${ }^{18}$ is considered the explicit point of departure of a 'civil' science policy. It pointed out that governments should be aware of their responsibilities towards $R \& D$, it sought public support for research and for "the promotion of a national policy for scientific research and education". It called for the establishment of a National Science Foundation (NSF). ${ }^{19}$

The Congressional approval of the National Science Foundation Act came about in 1950 , though not without a long debate, including a veto of the text by President Truman in 1947. The NSF emerged with the function of the general formulation of public policy, and to "evaluate scientific research promoted by the federal agencies". It could be assumed from the debate that NSF could take up the task of co-ordinating government activity in scientific research, and adopt the role of scientific advisor to the President.

However, after several frustrated attempts to make the agency an effective co-ordinating body, the NSF gave up its co-ordinating powers in 1957. The problem was that it had interests in R\&D similar to other agencies in the American govern- 
ment, and it lacked the authority to supervise relevant activities of other departments and agencies, and to offer political advice at a high level.

The debate on co-ordination re-emerged in the USA in 1957, after the Soviet success with Sputnik. Eisenhower named a Special Assistant for Science and Technology, and placed the Science Advisory Committee in direct line to the Presidency. But it was in Congress that the proposal for the creation of a US Department of Science was put forward.

Senator Hubert Humphrey defended the establishment of a body which would include all the branches of scientific research of the numerous existing governmental agencies. The Secretary of the Department, with Cabinet status, could give greater national importance to science, avoid duplication, and become a link between Congress and the President in these matters.

The basic problem ${ }^{21}$ was that, despite its co-ordinating powers, it would not reach out to the R\&D activities of sector-orientated departments. In the opinion of the experts, this would have led the Secretary of Science to compete, as opposed to co-ordinate, with his Cabinet colleagues for resources.

Don K Price ${ }^{n}$ made an assessment of the problems which this proposal entailed within the American system of fragmented sovereignty. A solution which left much R\&D outside the scope of the new Department was doomed to failure, given that it could not easily co-ordinate while competing for public funds for research. ${ }^{23}$

The opposition to the proposed Department was led by the AAAS (American Association for the Advancement of Science) but, in general, it was rooted in scientists' dislike of centralisation and a "profound number of administrative and political principles". ${ }^{4}$ Owing to an alliance between scientists and programme administrators in existing agencies, the proposal was defeated. Public policies were spread out under the supervision of administrators and leaders of public research agencies.

Thus for many years, despite the existence of many research priorities set up by agencies or by government departments, US scientists have been opposed to centralised co-ordination. Laissez-faire was the dominant ideology; money was available to science to use largely as it wished. The situation has survived, and the USA is representative of a system in which there is a lack of co-ordination of science, technology and innovation policies. 25

\section{Diffusion of science policy}

The rest of the western world generally followed a quite different path. The appearance of science on government agendas was generally brought about through a process of information diffusion, facilitated by agencies specialising in international cooperation, like OECD or UNESCO.
The need for co-operation, and to speed up the interchange of experiences and information among nations, partially explains why OECD was able to act as a catalyst in the international debate on several specific problems of science policy. ${ }^{26} \mathrm{On}$ the other hand, this relevance of science policy was not independent of the expansion and greater social strength of research and academic groups in member countries. ${ }^{27}$

In 1961, the General Secretariat of OECD proposed to establish an ad hoc Advice Group in Science Policy. It produced a report entitled Science and the Policies of Governments. The Implications of Science and Technology for National and International Affairs. But the quantum leap came about on 3-4 October 1963, when the ministers responsible for science in 22 countries met in Paris. At this time, very few nations had explicit science policies or mechanisms for its coordination. In the next ministerial meeting, two years later, the situation had changed drastically, and most western states had institutions specialising in science policy.

Despite the formality and negotiation which always characterises these meetings, there were two clear positions held amongst the nations represented concerning how science policies should be presented. In the final conclusions, apart from safeguarding the basic freedom of scientific research, it was recognised that "institutions and procedures to complete these tasks will vary from one country to another". 28

In the summary of the meeting, ${ }^{29}$ differences of attitude on the question of co-ordination amongst the most important countries can be observed. The French and German representatives supported a differentiated budget for science, for its symbolic value and as an effective instrument of coordination. This was opposed by the representatives of the USA, who claimed that research should depend on the aims of existing agencies, and that the science budget was nothing more than an aggregate of these agencies' budgets. On institutions being responsible for science policy, Germany emphasised the usefulness of having a general nationally-based co-ordinating structure, as opposed to the position of the US use of advice and support committees.

Spain was represented by the then Minister of Education, Manuel Lora Tamayo and, judging by later decisions, the Spanish position was closer to that held by the USA. This attitude is not surprising, given that the Spanish political regime of those times was trying to open up to the outside world with the support of the USA.

From a more formal perspective, the impact of the meeting on the non-existent 'Spanish science policy' could be discerned in the financial fund" run by CAICYT. ${ }^{31}$ This encouraged all matters related to science to be made more relevant, and this was particularly so after the OECD report on 
science policies in Spain in 1971, in which the resources assigned for $S \& T$ were assessed as very few.

While in most of the western world, R\&D and the development and consolidation of science policies were moving forward at a fair pace, given continuous increases in financial support, the situation in Spain was one of stagnation. ${ }^{32}$ This was only to be expected given the anti-Franco character of the universities and the few public research centres. ${ }^{33}$ It is not surprising that the attitude of the authorities was not very favourable towards science.

\section{Democratic transition}

During the 1970s, several changes came about in the 'blind' support which S\&T had previously enjoyed in many countries. Two new ideas arose: technology assessment, and the evaluation of research results and of S\&T policies. However, in Spain, neither during the democratic transition of the late 1970s nor during the launch of the science/technology system reform process, did these new concerns draw sufficient attention. ${ }^{34}$

Analysts of Spain in the 1970s agree that the circumstances brought about by the political legacy of Franco and by the difficulties of the democratic transition and the international economic crisis were exceptional and cumulative. ${ }^{35}$ The style of Franco;s public policy ${ }^{36}$ and the bureaucracy which survived the Civil War, although somewhat rejuvenated by the new technocracy of the Opus Dei, did not help the consideration of science policy as a government priority.

The temporary abandonment of scientific matters in Spain was caused by the central concerns of the democratic transition itself. The absence of any reference ${ }^{37}$ to scientific and technological research in the Pactos de la Moncloa ${ }^{38}$ is a very significant indication of Spanish political priorities at the end of the 1970s.

From 1976 onwards, economic recovery remained the focus for the Centrist (UCD) government, which concentrated on urgent matters which required considerable resources and effort (apart from the political and constitutional stability which

\section{During the transition to democracy science and technology policy in Spain had to take a back seat so that the government could concentrate on the matters of urgency such as inflation, industrial renewal and unemployment}

was necessary), such as inflation, industrial renewal, and unemployment. Thus, the seriousness of the economic crisis was also a factor in the temporary abandonment of science policy during these years.

However, some progress was made. For example, following an initiative of the World Bank in 1978, the Centre for Industrial Technology Development (CDTI) was established. But in general, science policy had had very little impact, given the internal instability of the governing party.

A Ministry of Universities and Research was established, but it did not survive for long. In a subsequent ministerial crisis, it was put under the Ministry of Education and Science. The last centrist government (with Mayor Zaragoza as Minister of Education) before the socialists came to office, had proposed a Law for Scientific and Technological Research. This had been an aim of several previous initiatives, and it finally come to the fore in June 1982, but it was not ratified by parliament before its dissolution.

\section{Appearance of S\&T policy}

Science had-to wait until the arrival of the first socialist government, towards the end of 1982, before a systematic plan of action could be implemented. In the mid-1980s a wide-ranging reform of the science/technology system, and the normative framework within which it operated, was underway with the parliamentary debate on the 'Science Law' (Law 13/86 for the Promotion and General Co-ordination of Scientific and Technical Research) and the preparations for the National R\&D Plan.

This all occurred after much reflection and analysis in which the strengths and weaknesses of the system had been examined in a way which, perhaps for the first time ever, revealed the main indicators of Spanish scientific and technological potential.

However, the diagnosis was discouraging, ${ }^{39}$ given that, while the average expenditure on R\&D in Europe was around $2 \%$ of gross domestic product (GDP), Spain's was hardly over $0.3 \%$. The fragmentation of responsibility for R\&D in ministerial departments ensured a complete lack of coordination, and the link between research and industry was just non-existent. Nevertheless, faced with this situation, there was considerable enthusiasm for change. In 1986, the Minister of Education and Science, J M Maravall, pointed out that "from the moment the present Government took office, it planned to establish a new structure for the Spanish system of S\& T". ".0

The first step in this process appeared to consist of the laying down of public policies for S\&T, something which neighbouring countries had done many years earlier. The reform process started by the 'Science Law' aimed to bring the national effort 
in R\&D up to levels similar to elsewhere in the European Community. Although it was not explicitly stated, the implicit objective was to raise the national overall R\&D expenditure to $1 \%$ of GDP by 1992 .

Secondly, a restructuring of the legal framework of government S\&T was attempted, the aim being to guarantee fluidity in the co-ordination of public initiatives. The hope was to overcome the two major problems other European countries had dealt with decades previously, with greater or lesser success: more financial and human resources for S\&T, and greater co-ordination of public initiatives and policies.

Reform came about at a highly favourable time. On the one hand, the socialist government had a strong mandate for action following its first electoral victory, with 202 out of 350 members of parliament. On the other hand, there was a high degree of awareness of scientific issues, in particular of university issues, among ministers, high-ranking government officials, and members of parliament, as a result of their social origins and their academic backgrounds. ${ }^{41}$

In addition, 'leadership' and 'policy entrepreneurs' were decisive factors which greatly helped the advance of the reforms. Leadership came from at a number of political and administrative levels. The Minister responsible was J M Maravall, while Carmina Virgili was the Secretary of State for Universities and Research. They had the support of A Pérez Rubalcaba, E Muñoz and E Lamo (all General Directors of the Ministry of Education and Science), and other officers of other ministries, in particular that of Industry and Energy. Last but not least, strong support was provided in parliament, with Senator Quintanilla at the fore.

The political-administrative-parliamentary alliance ensured the proper functioning of the reforms via action in the diverse political arenas. It included close collaboration between the Ministry of Education and Science, those who ran the Science and Technology Policy, and the President of the Mixed Congress-Senate Commission on Science and Technology.

This reformist zeal attracted some interest outside Spain. The international scientific media observed this process with some sympathy. New Scientist ${ }^{42}$ and the Financial Times ${ }^{43}$ published articles about it. Nature ${ }^{44}$ published an extensive re port on the interesting attempt by Spain to develop S\&T.

These were also the years of greatest attention to Spain's democratic transition. Later, $L a R e$ cherche ${ }^{45}$ showed concern for the development of research in Spain, and more recently, Nature has put Spain back on the map, although this time to draw attention to the Spanish political crisis in S\&T. ${ }^{46}$ This raises the question of a balanced assessment of the development of the system of public policies in S\&T.
The institutional solutions implemented during the restructuring of Spanish science/technology provided a very unstable basis for the distribution of power, and especially, put science in a very vulnerable position under the Government

\section{Institutional structure}

Institutions matter, but when considering public policies, the dominant analytical tradition (economics) tends to emphasise the substantive issues, and is little concerned with the institutional reality. Political science tends to be concerned with procedural aspects, implementation, and other characteristics of the policy-making process. Our concerns are more akin to this approach.

The debate on the best form of institutions to maximise the efficiency of S\&T policy is as old as science policy itself. However, this debate, especially on co-ordination, has concerned policymakers more than academics, with some exceptions, such as Price (1954) and Brickman (1979).

In the report ${ }^{47}$ prepared for parliament for the 'Science Law Project', it was pointed out that there were four different models of institutional organisation of S\&T in government. ${ }^{48}$ Of these, the preferred one was a co-ordinated system, with an assessment procedure, the function of which was to determine priorities (the National R\&D Plan), and a political and administrative mechanism of government to regulate science (the Interministerial Commission for Science and Technology, CICYT). This was granted an administrative infrastructure for its support (the General Secretariat for the National R\&D Plan), which formed a part of the Ministry of Education and Science, at the level of Directorate General ${ }^{49}$ (see Figure 1).

Although the criticisms of so-called 'coordinated models' were well-known during the mid-1980s, the Spanish approach was generally optimistic. It tried to move from co-ordination (Interministerial Commission, General Council, and Advisory Council) towards consensus (the National Plan, the budgetary unit of R\&D), following the recommendations of the Lamontagne Committee in Canada.$^{50}$ The basis of the institutional structure was the strong co-operation, almost a 'honeymoon', between the Ministries of Education and Science, and Industry and Energy.

Our view is that the institutional and organisational solutions implemented during the restructuring of the Spanish science/technology system 


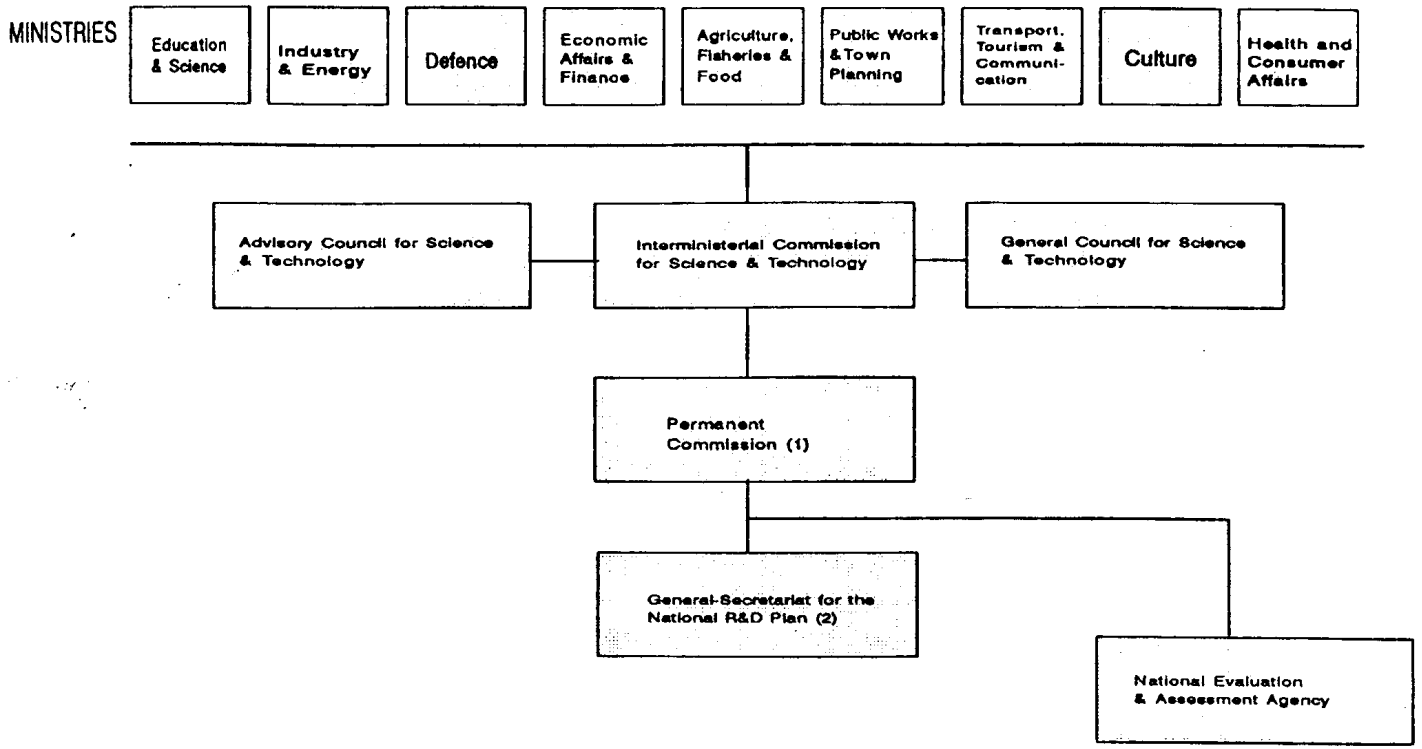

Figure 1. Government structure for science and technology in Spain as proposed by law 13/1986

Notes: 1. Representative only of three Ministries: Education and Science, Industry and Energy, and Economic Affairs and Finance 2. Administrative dependence of the Ministry of Education and Science.

provided a very unstable basis for the distribution of power, and especially, put science in a very vulnerable position under the government. It would have clear implications for its later development.

The fundamental basis of co-ordination lay in the National R\&D Plan, and its ability to concentrate budget funds from several sectors, with the aim of guaranteeing the viability of the CICYT. In this scheme, the highest accountable position in S\&T policy and in interdepartmental coordination is occupied by the General Secretary of the National R\&D Plan, with the status of Director General. He depended administratively on the Secretary of State for Universities and Research (who also has his 'own' funds for R\&D, the 'General Promotion of Knowledge Programme'). In turn, the Secretary of State depends on the Minister of Education and Science, who is frequently forced to make difficult political decisions on the basis of priorities determined by the electoral sensitivity of disparate issues, such as general education, training, sport or science.

The priority given to science by the Spanish government is still not high compared with France, Germany, Italy and, more recently, Great Britain (under John Major, who, according to Nature "copied the Ministry of Science proposals from the Labour programme"s1). All have a minister responsible for political action and co-ordination.

For Spain, the position of science in government is precarious, given that the highest position in S\&T policy (that of the Secretary General of the
National R\&D Plan) has only the status of Director General. Although it is his task to run the National R\&D Budget, he must compete against other offices of the same status under the same Secretary of State, including the Director General of Scientific and Technical Research.

The conflict in national priorities and their departmental dispersal (the most relevant currently are the National R\&D Budget, Education Budget, Technology and Industry Budget, Defence Budget, and the Health Budget) makes political selection rather difficult. The struggles, as in other countries, are not based on the optimisation of the results of public policies, but are of another kind, and to succeed, an alliance with the Treasury tends to be decisive.

The final proposal (the Interministerial Commission for Science and Technology) lacks, in practice, the administrative authority to define policies, and particularly to co-ordinate the initiatives of other departments. The system suffered from a structural weakness: it did not have enough status, and was 'superimposed' by the action of the only' two relevant Interministerial Commissions (the Commission of Sub-secretaries and the Delegate Commission of Economic Affairs, which meet frequently and under the guidance of the Vice President of the Government).

Scholars of Spanish administration have traditionally said that if the 'dreams of the just' want to be realised, the best thing to do is to create an interministerial commission to deal with it. ${ }^{52}$ This minimalist approach was also criticised eventually 
by the OECD in 1987, pointing out the poor administrative quality of the institution in charge of science in Spain.s3

The distribution of responsibility and power among ministries could have made the CICYT a forum for discussion between Director Generals of different ministries. In the beginning, this situation was countered by the rise of voluntary policy entrepreneurs. The personal enthusiasm and the combined effort of politicians, managers, and members of parliament, all temporarily drew attention away from the deficiencies of the proposed institutional structure, and avoided its immediate collapse.

However, the leadership of a minister and a group of individuals ('policy entrepreneurs') is too complex to survive long-term, particularly when there is also electoral instability. The lessons learned from the uncoordinated models show that restrictions resulting from the absence of coordination at the highest level could be overcome only when there is strong leadership.

On the other hand, the perennial problem is that historically the political agenda at the top has been very much determined in Spain by issues of foreign policy and macro-economics, and only the direct association of S\&T with these can guarantee them strong presidential support.

\section{A critical assessment}

The literature on S\&T policy has developed arguments which strengthen our analysis. Firstly, the way in which the possibilities for policy-making are determined by political structures. ${ }^{s 5}$ Secondly, the detrimental influence of the electoral four-year cycle on S\&T, on policies and on the attainment of results. ${ }^{56}$ Thirdly, and this applies especially to systems in which there is no strong co-ordinating structure (such as in Spain and the USA), the need for clear leadership, of strong and continued "presidential involvement", s7 so that proposed S\&T policies have a chance of succeeding. Lastly, there is a need for the emergence of policy entrepreneurs $^{\text {s8 }}$ to ensure the success of proposed policies.

Early on, the two principal ministries involved in the agreement, Education and Science, and Industry and Energy, became distanced from each other. Later, budgetary difficulties emerged between the National R\&D Plan and sectoral initiatives in R\&D. The Mixed Congress-Senate Commission on $R \& D$ appeared to lose its function in the early stages of the most recent legislature (1989-1993). Finally, the approval of a separate plan by the Ministry of Industry and Energy, the PATI (Programme for Technological and Industrial Action), without co-ordination of aims or objectives with the National R\&D Plan, is highly symptomatic of the situation.
The fragmentation of power in S\&T in countries with scarce resources is a major limitation on action, ${ }^{59}$ but it can also become a mechanism which facilitates access to, and 'colonisation' of, particular areas of public policy by certain special interest groups (such as scientists and corporations working in advanced technology). These 'pluralistic' policy-making practices, as they are called in the USA, show how fragmented decision-making takes priority over national decision-making, and this allows easy access by special interest groups to the policy-making arena.

The scientific communities, which had not previously had their interests represented in any way, have now organised themselves. The committees, set up to make assessments and decisions on the public funding (decided by those in political power) of R\&D in several scientific fields, have favoured this social organisation, even if at present it is only a way of managing the resources which the state makes available to S\&T.

It is interesting to observe how an effort to intervene in support of S\&T can have unexpected effects. These ought to be analysed, even if it means presupposing the success of the reforms. A public policy, promoted by civil servants and politicians (in this case, with private interests in the matter), in the absence of organised groups of scientists, could contribute to the decisive organisation of their interests, with the aim of eventually influencing the policy in question. ${ }^{60}$

On the other hand, some writers ${ }^{61}$ maintain that we must understand the history of science policy from the standpoint of the access of scientists, as a special interest group, to financial resources; and later their ascent, as experts, into political power. There has been much talk for many years of the peculiarities of this 'social contract'. In the early $60 \mathrm{~s}$, Don K Price pointed out that science had found a unique arrangement in the history of public administration, given that "it has become the only group of institutions for which funding is allocated on trust alone, and under agreements which protect the autonomy, if not the monastic peace of the laboratory".62

The groups which have colonised public policy operate on an ideology which feeds the public funding of S\&T in Spain. It appears to be an ideology of a collective organisation of science, with autonomy, the assigning of its own priorities, and self-evaluation. It is a model which Polanyi immortalised in the Science Republic, which he expressed as the "coordination through the mutual adjustment of independent initiatives". ${ }^{63}$

A similar analysis could be made of the technological programmes or industrial innovation policy. The interests of 'innovative' companies are more closely associated to PATI; the development funds for innovation technology for corporations are run mostly by public bodies (such as the CDTI), which benefit from considerable mobility and inter- 
changeability with the managers of the companies. In this case, the ideology which feeds the transfer of resources is, 'what is good for business is good for the country'. In fact, and with reference to technology, it is common to talk of a 'technology pork barrel'. 64

Such public policies tend to assume rational behaviour from politicians and civil servants, expressed in the maximising of their power through maximising their domain (which grows as the funds they distribution are spread over more projects) The problem is that this system does not lead to an optimal efficiency in public policies. ${ }^{\circ}$ Ultimately, we could be facing a case of a relatively stable, functional solution, given that it allows for a kind of 'pork barrel' for the business and scientific communities.

This access to particular policy-making interests, the 'colonisation' of S\&T policy by special interest groups, has not emerged under the corporatist model ${ }^{66}$ but under a clientelist model. ${ }^{67}$

The de facto compromise between S\&T policymakers and their clients (scientists and, via public technology agencies, firms) does not aim to manage collective interests, but to manage those of particular scientists or firms, which use them to their benefit. The client networks, which are largely grouped by scientific specialisations, do not display a consensus, but act rather as a network of personal affiliations which operate through the individual use of state resources.

It looks as if the client-based models of policy-making have now become important again, as they were (according to Gunther (1980)) in Franco's Spain. This is reflected in the current lack of any assessment of S\&T and in the absence of social control. To assess policies would be to affect them, not through the influence of individual decision-makers, but by giving way to a series of generalisations which would eventually be evaluated by relevant groups. ${ }^{68}$

Finally, it appears that S\&T policies reflect general policies, ${ }^{69}$ the country's style of policy, ${ }^{70}$ and the peculiarities of the policy-making process. ${ }^{71}$

\section{Summary and conclusions}

Science and technology were not priorities in public policy in Spain until the Socialists took office in the mid-70s. Then they became an important part of the government agenda, more as the result of the international diffusion of public S\&T policies and of the emergence of policy entrepreneurs, than of the organised action of interest groups.

The initiatives and reforms of the rationalisation process, aimed to reinforce the coordination of public initiative in S\&T, but considerable institutional weakness limited the result. This weakness was not immediately perceived because of:

\section{The access to particular policy-making interests, the 'colonisation' of science and technology policy by special interest groups, has not emerged under the corporatist model but under the clientilistic model}

- strong leadership, and the activities of policy entrepreneurs,

- the freezing of the power of traditional bureaucracies in the first Socialist government, and

- the absence of mechanisms to represent those with an interest in its success.

Recent developments appear to point towards the disappearance of all mechanisms of government co-ordination in S\&T, independently of the merely budgetary functions of the Treasury. The impossibility of continuing the debate on S\&T policies within the Interministerial Commission (CICYT) is well-known. The representatives of other ministries (and possibly also the Secretary of State for Universities and Research himself) see the General Secretary of the National R\&D Plan simply as a representative of the Ministry of Education and Science, to whom they have no obligations.

In this situation, the functional institutions (the ministries) set the pace of the negotiations for government policies. The disappearance of leadership in the reform process appears to have brought a recovery in power around the departmental bureaucracies and the politicians responsible for them. The consequences for government action in $S \& T$ is very serious, given the low administrative status of the institutions involved.

The weakness of the institutional, administrative and politics (and the difficulties involved in substituting them for leadership and voluntary action) has meant that these issues come low in government priorities.

The breaking up of S\&T policy, together with the disappearance of both policy entrepreneurs and strong leadership, has made it possible for some interests to have access to the policy-making process, under the constraints of a client-based structure. Systems of this kind have a tendency to consolidate themselves, but there are strong pressures in the S\&T policy against this. For this reason, and given the conflict between a Treasury seeking reduced expenditure and scientists seeking more funding, there is now little stability in the system.

There are also many younger scientists hoping to be incorporated into a stable community of researchers. And there is a shift of public resources towards the private sector, which is also happening 
elsewhere, ${ }^{n}$ and which could upset this balance further.

\section{Notes}

1. Aonso Zaldivar, Castells et al, 1992.

2. The President of Spain. Felipe González, in the prologue to Nuevas Tecnologlas, Economia y Sociedad en España, emphasised the importance of S\&T thus: "to face the challenge of technological renewal... is the final indispensable step for the success of the modernization process" and "the Government is prepared to place our nation firmly in the third industrial revolution" (Castells et al, 1986).

3. Unión del Centro Democrático (UCD) was the name of the centrist political party that governed in Spain from the first democratic elections in 1977 to the end of 1982.

4. The significance of the more recent 'abandonment' of S\&T policies by the last Socialist Cabinet, and again by the presidency of Felipe González ought to be noted. That is clear in the Convergence Programme designed by the Spanish Government in relation to the European Community. See the article by E Muñoz and L Sanz, "Ni ciencia, ni tecnología", EI País, 5 June 1992.

5. The improvement of the available statistical data, as well as the development of bibliometric and patent studies, has become evident in the proliferation of analyses of the 'Spanish science/technology system". Among these, we should note, for their general character, the work produced at the University of Salamanca, under Miguel A Quintanilla (Arbor, 554-555, Fe 554-555, February-Mrch 1992), under the title EPOC Project (Evaluation of Science Policies). We have also contributed to the analyses of the position of S\&T in Spain and their relation
to society in previous works: Muñoz and Ornia, 1986; SanzMenéndez and Goicolea, 1987; Sanz-Menéndez and García, 1990; Sanz-Menéndez and Pfretzschner, 1992; Sanz-Menéndez and Muñoz, 1994.

6. See Nelson, 1959; Arrow, 1962; Dasgupta, 1987; Stoneman, 1987.

7. See Nelson and Winter, 1982; Mowery and Rosenberg, 1989; Dosi, 1991; Nelson, 1993

8. Shils, 1968 .

9. Salomon, 1991.

10. The Law $13 / 86$ for Promotion and General Co-ordination of Scientific and Technical Research (Ley de Promoción y Coordinación General de la Investigación Científica y Técnica) and the National Research and Development Plan (Plan and the National Research and Development Plan (Plan Tecnológico).

11. Sanz-Menéndez and Muñoz, 1994.

12. Quintanilla, 1992; Sanz-Menéndez and Muñoz, 1993.

13. Although this work essentially concentrates on the coordination problems of the state-fevel administration, two ther serious areas of lack of co-ordination should be noted. On the one hand, the activism of some regional governments contributes to the co-ordination difficulties between the numerous administrations. On the other hand, the existence of a European S\&T policy gives room for a growing tendency by the Government to ignore national objectives where S\&T are concerned.

14. Crane 1977.

15. The 13/86 Law establishes an interdepartmental Commission (CICYT: Comisión Interministerial de Ciencia y Tecnologia Interministerial Commission for Science and Technology) instead of a Ministry, as responsible for S\&T policy.

16. Price, 1954; Gilpin and Wright, 1964; Kaplan, 1965; Lakoff, 1966; Shils, 1968; Salomon, 1970; Sapolsky, 1975; Ronayne, 1984; Gummett, 1992

17. See Salomon, 1970.

18. Bush, 1945.

19 In the United States, while the Bush Report was being debated, the Steelman Report (Science and Public Policy, 1947) appeared, recommending the elimination of the deficit in the area of "scientific assessment".

20. Dupré and Lakoff, 1962

21. Humphrey, 1960

22. Price, 1959, page 762.

23. Nonetheless, the existence of this Science and Technology
Department, with horizontal co-ordinating powers, is one of the most common solutions today in the administrative bodies of western European governments.

24. Dupré and Lakoff, 1962, page 70.

25. Roessner, 1988; Rothwell and Zegwelt, 1981.

26. Salomon, 1977, pages 52-53.

27. Dickson, 1984

28. Mesthene, 1965, page 131

29. Mesthene, 1965.

30. Fondo Nacional para la Promoción de la Investigación Científica y Técnica (National Fund for the Promotion of Scientific and Technical Research).

31. Comisión Asesora para la Investigación Científica y Técnica (Commission for the Assessment of Scientific and Technical Research).

32. Sanz-Menéndez and Mur̃oz, 1992.

33. In that period the Consejo Superior de Investigaciones Cientificas (CSIC, National Centre for Scientific Research) and the Junta de Energía Nuclear (JEN, Nuclear Energy Authority) were two of the most important centres of political opposition.

34. In Spain there has hardly been any concern about the question of technology assessment. The second socialist legislature attempted to institutionalise technology assessment mechanisms with a Parliamentary Office for Technology Assessment, but the dissolution of Parliament and the loss of the seat occupied by Senator Quintanilla, the main propo(the abandonment of the project (see Quintanilla, 1989).

On the other hand, in Spain, the only evaluation mechanism in existence in science policy comes from peer review, which is managed through the Agencia Nacional de Evaluación y Prospectiva (ANEP, National Evaluation and Assessment Agency), for the awarding of financial resources for $R \& D$ projects. There is no evaluation of S\&T policies (the authors projects. Ther

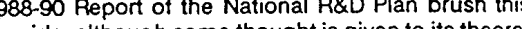
question aside, although some thought is given to its theore tical aspects (CICYT, 1991)), nor is there an evaluation of firm research supported by public funding (the work on CDTI by Fontela, Pulido, Sánchez and Vicens (1992) can be seen from this perspective), nor is there any evaluation of management of the programmes for public support of the R\&D.

This lack of evaluation is damaging to S\&T and to the policies which aim to promote it, given that it increases its policies which aim to promote it, given that it increases its
vulnerability. Without making a critical assessment of revulnerability. Without making a critical assessment of reresources to society and the state lacks legitimacy. In any case, as can be expected, it does not look as though S\&T policies can avoid the influence of an administration which completely lacks the practice of evaluating its own activities (Beltrán, 1991; Subirats, 1989).

35. García Delgado, 1990

36. Gunther, 1980

37. Sanz-Menéndez and Muñoz, 1994

38. The Pactos de la Moncloa, signed in 1978 by all the political groups of the national parliamentary spectrum, was a general agreement on political priorities for the consolidation of democracy in Spain.

39. Muñoz and Ornia, 1986

40. Muñoz and Ornia, 1986

41. It should be noted that most of those involved were members of the bodies of the state civil service for 'non-tenure' individuals seeking membership of the civil service) from universities or research centres.

42. Herman, 1983.

43. December 9 th, 1983.

44. Nature, 1986.

45. Barrere, 1990

46. Abbot, 1992; Segurado, 1992.

47. Included in Muñoz and Ornia, 1986.

48. Ronayne, 1984.

49. The position of Director General corresponds to the thirc :evel in the Spanish state administration, under Minister and Secretary of State on the political hierarchy, and Sub-secreiary in the administrative hierarchy. But more recently, the tend. ency has been towards moving to a fourth level, due to the expansion of the post of General Secretary, following Secretary of State on the political side.

50. Senate Special Committee on Science Policy, 1970

51. Nature, 23 April 1992

52. Nieto, 1984 
53. One of the clearest criticisms of the OECD reports of the Spanish situation was the two-headed character of the authority on S\&T. It was not clearly stated in the final report because the argument was rejected by the Spanish auth orities, but in particular the French expert, Professor Pigagniol, thought it one of the greatest weakness of the system. It turned out to be prophetic. We owe this to Paloma Sanhesident of 作 OECD)

54. Katz, 1978; Lambright and Rahm, 1988

55. Mogee, 1988.

56. Lambright and Rahm, 1988.

57. Katz, 1978

58. Atkinson, 1991.

59. Ronayn, 1991.

60. Ronayne, 1984 . which we describe tt can be found in the agricultural policy which we describe. It can be found in the agricultural policy of the New Deal in the United States. The approval, in 1933 , of the Agricultural Adjustment Administration (AAA) proved to be very useful for the organisation of the interests of commercial agriculturalists, which had previously no collective representation. It contributed to the creation of a representative organisation for agriculturalists (the American Farm Bureau Federation) which, from that time on, obtained considerable political benefits, as a result of the activities of the AAA, and became one of the major Washington lobbies (see Skocpol and Finegold, 1982)

61. Dickson, 1984.

62. Price, 196, page 20

63. See Polanyi, 1962. The problem is that the "invisible hand" which, according to Polanyi, guides science, makes state intervention or participation in the definition of the objectives or priorities of S\&T not only unnecessary but inconvenient. Under this concept, society and government do not appear Under this concept, society and government do not appear to be able to demand any responsibility of scientists and and manage S\&T policies. With this model, neither the ad justment of policies to national priorities, nor the attainment of objectives as efficiently as possible, become matters of urgency.

64. Cohen and Noll, 1991.

65. Weingast, Shepsle and Johnsen, 1981.

66. Lehmbruch and Schmitter, 1982.

67. LaPalombara, 1964.

68. Weiss, 1988

69. Roessner, 1988.

70. Richardson, 1982; Subirats, 1991.

71. Atkinson, 1991

72. Dickson, 1984; Williams, 1988

\section{References}

A Abbott (1992). "The young and the restless", Nature, 360, 10 December 1992, page 502.

C Alonso Zaldivar, M Castells et al (1992), Spain, Beyond Myths (Alianza Ed, Madrid)

KJ Arrow (1962), "Economic welfare and the allocation of resour. ces for invention", in NBER, The Rate and Direction of Inventive Activity: Economic and Social Factors (Princeton University Press, Princeton, 1962) pages 609-625.

R D Atkinson (1991), "Innovation policy making in a federalist system: lessons from the states for US federal innovation policy making", Research Policy, 20(6), December, pages 559-577.

M Barrere (1990), "Espagne: le flamenco de la science", La Recherche, 21 (223), July-August, pages 979-985.

MBeltrán (1991), La productividad en la Administración Española: un anàlisis comparado (IEP. Ministerio de Economía y Hacienda, Madrid).

R Brickman (1979), "Comparative approaches to R\&D policy coordination", Policy Sciences, 11(1), August, pages 73-91.

$\checkmark$ Bush (1945), Science, The Endless Frontier: A Report to the President on a Program for Postwar Scientific Research (National Science Foundation, Washington, reprinted).

M Castells et al (1986). Nuevas Tecnologias, Economia y Sociedad en Espana (Alianza, Madrid, 2 volumes).

CICYT (1991), Memoria de desarrollo del Plan Nacional de $1+D$ en el periodo 1988-1990 (Comisión Interministerial de Ciencia
Y Tecnologia, Madrid, 2 volumes)

L R Cohen and R G Noll (editors) (1991), The Technology Pork Barrel (The Brookings Intitution, Washington DC).

D Crane (1977), "Technology innovation in developing countries: a review of the literature ". Research Policy, 6(4), October 1977, pages $374-395$

P Dasgupta (1987), "The economic theory of technology policy: an introduction", in P Dasgupta and P Stoneman (editors) (1987). Economic Policy and Technology Performance (Cambridge University Press, Cambridge) pages 7-23.

D Dickson (1984). The New Politics of Science (University of Chicago Press, Chicago-London, 2nd edition)

G Dosi (1991), "Perspectives on evolutionary theory", Science and Public Policy, 18(6), December, pages 353-361.

J S Dupré and S A Lakoff (1962), Science and Nation. Policy and Politics (Prentice-Hall, Englewood Cliffs (NJ)).

E Fontela, A Pulido, M P Sánchez and J Vicens (1992), Evaluación de la Actuación del CDTI en apoyo a la l+D (Centro para el Desarrollo Tecnologico Industrial, Madrid).

J L García Delgado (editor) (1990), La Economia Española en la Transición y la Democracia (1973-1986) (Centro de Investigaciones Sociológicas, Madrid).

R Gilpin and C Wright (editors) (1964), Scientist and Nationa Policy-Making (Columbia University Press, New YorkLondon).

PGummett (1992), "Science and technology policy", in M Hawkwsworth and M Kogan (editors), Encyclopedia of Government and Politics, vol 2 (Routledge, London-New York) pages 759-776.

R Gunther (1980), Public Policy in a No-Party State (University of California Press, Berkeley-Los Angeles-London).

R Herman (1983), "Spanish science tries to grow up", New Scien tist, $99(1377), 29$ September, pages 933-938.

H H Humphrey (1960), "The need for a department of science", Annals of the American Academy of Political and Social Science, 327, January, page 34 .

N Kaplan (editor) (1965), Science and Society (Rand McNally. Chicago).

JE Katz (1978), Presidential Politics and Science Policy (Praeger, New York-London)

SA Lakoff (editor) (1966), Knowledge and Power (The Free Press, New York).

W H Lambright and D Rahm (1988), "Presidential management of technology", in M E Kraft and N J Vig (editors) (1988), Technology and Politics (Duke University Press, DurhamLondon) pages 81-97.

$\mathrm{J}$ LaPalombara (1964), Interest Groups in Italian Politics (Princeton University Press, Princeton).

G Lehmbruch and P C Schimitter (editors) (1982), Patterns of Corporatist Policy making (Sage, London-Beverly Hills (Ca)).

E G Mesthene (editor) (1965). Ministers Talk about Science (OECD, Paris)

$M E$ Mogee (1988). "Knowledge and politics in innovation policy design", in J D Roessner (editor) (1988), Government Innovation Policy (MacMillan, London) pages 37-47.

D Mowery and N Rosenberg (1989), Technology and the Pursuit of Economic Growth (Cambridge University Press, Cambridge).

E Muñoz and F Ornia (1986), Ciencia y Tecnología una oportunidad para España (Ministerio de Educación y Ciencia-Aguilar, Madrid).

Nature (1986), "Science in Iberia. A renaissance in the making", Nature, 324, 27 November, pages 313-332.

R Nelson and SWinter (1982), An evolutionary theory of economic change (Belknap-Harvard University Press, Cambridge (Ma)).

R R Nelson (1959), "The simple economics of basic scientific research", The Journal of Political Economy, LXVII(3), June, pages $207-306$

R R Nelson (1993), The Co-Evolution of Technologies and Institutions (Columbia University, September, draft)

A Nieto (1984), La organización del desgobierno (Ariel, Barcelona, 1st reprint).

OECD (1971), Politicas nacionales de la Ciencia: España (Ministerio de Educación y Ciencia, Madrid).

OECD (1987), Innovation policy: Spain (OECD, Paris)

M Polanyi (1962), "The republic of science", Minerva, 1(1), Autumn, pages 54-73

D K Price (1954), Government and Science (New York University Press, New York).

D K Price (1959), "Organization of science here and abroad", Science, 129, 20 March, page 762 . 


\section{Vicissitudes of Spanish S\&T policy}

DK Price (1962), "The scientific establishment", in R Gilpin and C Wright (editors) (1964), Scientists and National Policy-Making (Columbia University Press, New York-London) pages 19-40.

M A Quintanilla (1992), "Recursos del sistema de Ciencia y Tocnologia", Arbor, 554-555, February-March, pages 31-76.

M A Quintanilla (editor) (1989), Evaluación parlamentaria de las opciones cientificas y tecnologicas (Centro de Estudios Constitucionales, Madrid).

J Richardson (editor) (1982), Policy Styles in Western Europe (George Allen and Unwin, London).

J D Roessner (1988), "Innovation policy in the United States: an overview of the issues", in J D Roessner (editor) Government Innovation Policy (MacMillan, London) pages 3-15.

$J$ Ronayne (1984), Science in Government (Edward Arnold, Caulfield (Australia)-London).

RRothwell and W Zegveld (1981), Industrial Innovation and Public Policy (Greenwood, Westport(CT)).

JJ Salomon (1970), Science et Politique (Ed du Seuil, Paris) (Science and Politics (Macmillan, London, 1973).

J-J Salomon (1977), "Science policy studies and the development of science policy", in I Spiegel-Rösing and D de S Price (editors) (1977), Science, Technology and Society (Sage, London-Beverly Hills (Ca)) pages 43-70.

JJ Salomon (1991), "Changing perspectives of science policy: insights into innovation process", Journal of Scientifc and Industrial Research, 50(2), February, pages 90-101.

L Sanz-Menéndez and C Garcia (1990), "Presente y perspectivas de la brecha tecnológica en la Comunidad Europea", in M Gamella and M Hernández (editors) (1990), Nuevas tecnologlas y orden económico internacional (Fundesco, Madrid) glas y orden

L Sanz-Menéndez and J Goicolea (1987), "Technology assessment and scientific policy in Spain", in EEC, Technology Assessment: An Opportunity for Europe (Government Printing Office, The Hague) pages 1-26

L Sanz-Menéndez and E Muñoz (1992), "Las políticas científicas y tecnologicas en españa: desde la autarquía a la transición", ALFOZ, 93/94, pages 46-62.

L Sanz-Menéndez and E Muñoz (1994), "Technology policy in
Spain", in G Aichholzer and G Schienstock (editors), Technology Policy: Towards an Integration of Social and Ecological Concerns (De Gruyter, Berlin-New York)

L Sanz-Menéndez and J Píetzschner (1992), "Política científica y gestión de la investigación: EI CSIC (1986-1990) en el sistema 

IM Sapolsky (1975), "Science policy", in F O Greenstein and N W Polsby (editors) (1975), Handbook of Political Science vol 6: Policies and Policy Making (Addison-Wesley, Reading (Ma)6: Policies and Policy Making (Addison-Westo
Menlo Park (Ca)-London) pages 79-110.

OG Segurado (1992), "Running out of steam...", Nature, 360, 10 December, pages $502-503$.

Senate Special Committee on Science Policy (1970), A Science Policy for Canada (1970-1976), 4 volumes.

E Shils (editor) (1968), Criteria for Scientific Development: Public Policy and National Goals OMIT Press, Cambridge (Ma)London.

T Skocpol and K Finegold (1982), "State capacity and economic intervention in the early new deal", Political Science Quarterly, 97 (2). Summer, pages 255-278.

J R Steelman (1947), Science and Public Policy, A report to the President, US President's Scientific Research Board (US Government Print Office. Washington), 5 volumes)

P Stoneman (1987). The Economic Analysis of Technology Policy (Clarendon Press, Oxford).

J Subirats (1989), Anàlisis de politicas públicas y eficacia de la Administración (INAP, Madrid).

J Subirats (1991), "El proceso de formación de políticas en España. Algunas hipótesis", Revista del Centro de Estudios Constitucionales, 9, May-August, pages 199-216.

B R Weingast, K A Shepsle and C Johnsen (1981), "The political economy of benefits and cost: a neoclassical approach to

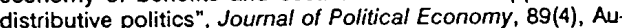
distributive politics",

gust, pages 642-664.
Weiss (1988), "Evaluation for decisions: is anybody there? Does anybody care?", Evaluation Practice, 9(1), February, pages $5-20$.

RWilliams (1988) "UK science and technology policy, controversy and advice", Political Quarterly, 59(2), June, pages 132-144. 